\title{
Identification of Key Pathways and Genes Related to the Development of Hair Follicle Cycle in Cashmere Goats
}

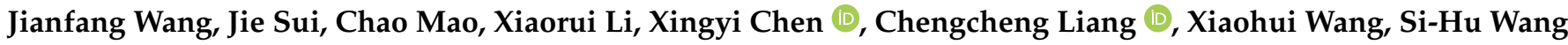 \\ and Cunling Jia *
}

Citation: Wang, J.; Sui, J.; Mao, C.; Li, X.; Chen, X.; Liang, C.; Wang, X.; Wang, S.-H.; Jia, C. Identification of Key Pathways and Genes Related to the Development of Hair Follicle Cycle in Cashmere Goats. Genes 2021, 12, 180. https://doi.org/10.3390/ genes12020180

\section{Academic Editors:}

Paolo Ajmone-Marsan and Peer Berg Received: 5 December 2020

Accepted: 22 January 2021

Published: 27 January 2021

Publisher's Note: MDPI stays neutral with regard to jurisdictional claims in published maps and institutional affiliations.

Copyright: (C) 2021 by the authors Licensee MDPI, Basel, Switzerland. This article is an open access article distributed under the terms and conditions of the Creative Commons Attribution (CC BY) license (https:// creativecommons.org/licenses/by/ $4.0 /)$.
College of Animal Science and Technology, Northwest A\&F University, Yangling 712100, Shaanxi, China; jfwang@nwsuaf.edu.cn (J.W.); suijie_on@163.com (J.S.); mc@nwafu.edu.cn (C.M.); lixiaorui012@163.com (X.L.); chenxingyi@nwafu.edu.cn (X.C.); lcc20151120@nwafu.edu.cn (C.L.); wangxh3607@nwafu.edu.cn (X.W.); sihumeng@126.com (S.-H.W.)

* Correspondence: linga2177@nwafu.edu.cn

\begin{abstract}
The development of hair follicle in cashmere goats shows significant periodic change, as with mice and humans. However, for cashmere goat with double-coat, the periodic change may be due to other regulatory molecules and signal pathways. To understand the mechanism of periodic development of hair follicle, we performed a weighted gene coexpression network analysis (WGCNA) to mine key genes and establish an interaction network by utilizing the NCBI public dataset. Ten coexpression modules, including 7689 protein-coding genes, were constructed by WGCNA, six of which are considered to be significantly related to the development of the hair follicle cycle. A functional enrichment analysis for each model showed that they are closely related to ECMreceptor interaction, focal adhesion, PI3K-Akt signaling pathway, estrogen signaling pathway, and so on. Combined with the analysis of differential expressed genes, 12 hub genes from coexpression modules were selected as candidate markers, i.e., COL1A1, C1QTNF6, COL1A2, AQP3, KRTAP3-1, KRTAP11-1, FA2H, NDUFS5, DERL2, MRPL14, ANTKMT and XAB2, which might be applied to improve cashmere production.
\end{abstract}

Keywords: hair follicle cycle; WGCNA; coexpression network; hub genes

\section{Introduction}

Hair is one of characteristics of mammals. Hair follicle (HF) is the key organ for hair growth, and it consists of two distinct parts. The upper permanent region is comprised of the infundibulum and isthmus, which are relatively stable, whiles the lower follicle is comprised of the hair bulb and suprabulbar region, which undergo periodic regeneration [1]. Follicular papilla in the hair bulb dictates the induction and maintenance of the follicular epithelial differentiation, and determines anagen duration, hair shaft diameter and length [1,2]. Hair follicles do not enter the self-renewal cycle until they are fully developed after birth, and experience growth (anagen), regression (catagen), and a rest period (telogen), followed hair shedding [3]. The cyclic change is similar in mammals, but the molecule regulatory mechanism may be different due to the different length of cycle and the species-specific morphologies of HF [4].

Cashmere goats are characterized by a double coat including wool and cashmere. Wool and cashmere are produced by two types of HF. Primary hair follicles (PHFs) produce wool while secondary hair follicles (SHFs) produce cashmere [5]. Studies have shown that the SHFs of cashmere goats undergo obvious periodic changes [6,7]. The structural characteristics of the SHFs directly affect the output and quality of cashmere. Cashmere is a luxurious material which is of great economic value in the textile industry [8]. It is, therefore, important to research the mechanism of the periodic development of HFs in order to improve cashmere performance through artificially adjusting the HF cycle. 
With the rapid development of high-throughput sequencing technology, some regulatory factors and signal pathways involved in the hair follicle cycle (HFC) have been found through differential expression gene (DEG) analysis and functional enrichment analysis. These well-known regulatory molecules and signal pathways include Wnt/ $\beta$ catenin [9-11], bone morphogenetic proteins (BMPs) [12,13], sonic hedgehog (SHH) [14], notch [15], fibroblast growth factors (FGFs) [16], transforming growth factors (TGFs) [17] and keratin-associated proteins (KRTAPs) [18], etc. Most of them were reported in mice and human, but for cashmere goat with a double-coat some other uncommon regulatory molecules, different signal pathways may be involved. Various researches and analysis methods have made it be possible to determine some unexpected links among the genes expressed in these pathways.

Based on the coat complexity of cashmere goat, it is necessary to systematically study the interconnectedness among genes. The network analysis is a global approach, in contrast to focusing on individual genes. Compared with publicly available cluster analysis statistics software like self-organizing map, hierarchical clustering and k-means [19], weighted gene coexpression network analysis (WGCNA) employs soft thresholding techniques, which results in weighted networks and yields highly robust biological results [20]. Moreover, WGCNA can make full use of the expression of all genes, combine Gene Ontology (GO) enrichment analysis, topology enrichment, KEGG enrichment analysis and gene regulatory network analysis, and identify hub genes [21-23]. WGCNA has shown its potential to unravel the gene regulatory architecture of complex traits [24-27] by clustering genes which are strongly correlated with phenotype or sample characteristics into a module [28].

Herein, we used WGCNA technology to explore the gene coexpression network and identify hub genes closely related to each stage of the HFC of cashmere goats, according to the correlation between genes and hair follicle development characteristics. Our results will provide some other pathways for further research of the regulation mechanism of the hair follicle regeneration cycle in cashmere goats.

\section{Materials and Methods}

\subsection{Data Sources}

Raw data (SRP145408) in this study were downloaded from the Sequence Read Archive database of the NCBI (https:/ / www.ncbi.nlm.nih.gov/) [18]. This dataset contained transcriptome sequencing information from skin tissues of three adult Inner Mongolia cashmere goats collected continuously once a month for 12 months. A total of 36 samples were used.

\subsection{Data Preprocessing}

The raw data were converted into FASTQ format by SRAtools (Version 2.8.1) software [29] and quality control was detected by FastQC (Version 0.11.9) (https://www. bioinformatics.babraham.ac.uk/projects/fastqc/). After filtered adaptor sequences and lowquality reads by Trimmomatic (Version 0.39) software [30], clean reads were mapped to the goat reference genome (ftp:/ /ftp.ensembl.org/pub/release-101/fasta/capra_hircus/dna/ using HISAT2 (version 2.2.0) [31,32]. Counts of the mapped reads were extracted by FeatureCounts [33] and the value of FPKM (Fragments per Kilobase of transcript per million) was obtained using StringTie (Version 2.1.2) [34] to normalize the mapped reads and construct the gene expression matrix for WGCNA analysis.

\subsection{The Construction of Weighted Gene Coexpression Network for HFC Development}

A weighted coexpression network was performed using WGCNA (version 1.69) [21], which was built in R 4.0.2 using RStudio (http:/ /www.rstudio.org), an integrated development environment for $R$. First of all, the expression matrix was standardized by $\log 2(\mathrm{FPKM}+1)$, and genes with expression standard deviations (SDs) of less than 0.5 were removed in each sample. Based on the correlations among samples, a clustering dendrogram was drawn to remove outliers. Then, a correlation matrix was constructed using 
pairwise Pearson Correlations among all genes. To achieve a scale-free network, an appropriate soft threshold power $\beta$ was employed to calculate the adjacency between genes by the pickSoftThreshold function. The power $\beta$ is a weighted parameter to highlight the strong correlation between genes. Finally, to identify gene modules, the topological overlap measure (TOM) was used to calculate the degree of correlation [20], and a hierarchical clustering tree was constructed according to the corresponding dissimilarity (1-TOM) with the minModuleSize 30 [35]. The genes with similar expression patterns were summarized in the same module by the module eigengenes (MEs) [36]. The modules with more than $75 \%$ similarity were merged by using the default tree height cut of 0.25 : MEDISSTHRES $=0.25$ in WGCNA [36,37].

\subsection{Screening Key Modules Related to HFC}

According to the characteristics of the growth and development of HFs in cashmere goat over 12 months [18], we divided the development of HFs into four stages: anagen (April-September), catagen (October and November), telogen (December-February), lasttelogen (March). In this study, the key modules related to the periodic regeneration of cashmere goat hair follicle were determined by calculating gene significance (GS) and module membership (MM) values simultaneously [38]. The GS was used to describe the correlation between MEs and HFC trait. The MM indicated the correlation between the gene expression profile and each ME [39]; the higher the correlation in the GS and MM, the more important the module which was associated with the trait [20]. The statistical significance of the correlation between the module and HFC was verified by the Pearson correlation [40]. The modules with $\mid$ cor $\mid>0.50$ (0.50 regarded as a moderate relationship) and $p<1 \times 10^{-4}$ (the smaller the $p$ value, the more significant the correlation was) were selected as key modules for further analysis [41].

\subsection{Enrichment Analysis of Genes in Key Modules}

The online tool g:profiler [42] (https: / / biit.cs.ut.ee/gprofiler/) was used to transform the module gene IDs and GO function annotation with default parameters. There were three sub-ontologies of $\mathrm{GO}$ annotation including biological process (BP), cellular component (CC) and molecular function (MF). GO terms with significant enrichment were selected according to adj-p-value $<0.05$. REVIGO (http://revigo.irb.hr/) was used to remove redundant GO terms. Kyoto Encyclopedia of Genes and Genomes (KEGG) pathway analysis was implemented by KOBAS 3.0 (http:/ / kobas.cbi.pku.edu.cn/kobas3/?t=1) with default parameters, and adj- $p$-value $<0.05$ was set as the screening condition for significant enrichment.

\subsection{Identification of Hub Genes Related to HFC}

In this study, hub genes were determined by two methods. One was to screen out hub genes based on GS and MM values. Genes with highest MM and highest GS in modules of interest were considered as candidates. Thus, the intramodular hub genes were chosen based $|\mathrm{GS}|>0.2,|\mathrm{MM}|>0.9$ with weighted $p$ value ( $p$.weighted) $<0.01$ [43]. The $p$.weighted was calculated by networkScreening function to check the significance of GS and MM, respectively. The other method was Maximal Que Centrality (MCC) algorithm [44] from plug-in cytoHubba in Cytoscape (Version 3.6.0) software [45]. The top ten genes ranked by MCC values were considered as hub candidates [46-49].

\subsection{Verification of Hub Genes Combined DEGs Analysis}

To determine the differences between expression of the hub genes in different periods, we firstly filtered and removed the genes from the count matrix with low coverage across all samples based on an average CPM value $<1$. Then, DEGs were screened from a particular period relative to other periods by the edgeR [50] in $\mathrm{R}$ package. The threshold of DEGs was set as $\mid \log 2$ fold change $\mid>1$ and FDR $<0.01$. Then, Venny 2.1.0 (https: //bioinfogp.cnb.csic.es/tools/venny/) was used to overlap DEGs and hub candidates. 


\subsection{Visualization of the Relationship Network between Hub Genes and Their Target Genes}

Based on the coexpression network of MEs, the subnetwork of differentially expressed hub genes interacting with their target genes were extracted and visualized using Gephi (version 0.9.2) [51,52]. Gephi "Modularity" function was used to classify individual nodes from the same identified module by WGCNA into communities to further interrogate the networks [53,54].

\section{Results}

\subsection{Profiles of Transcriptome Data}

Raw transcriptome data from 36 skin samples were filtered by removing adapter and low-quality fragments to obtain clean reads. The rates of these reads mapping to the reference genome were over 96\% (Supplementary Materials Table S1). After normalizing and annotating the mapped reads, a total of 14,240 genes were found. A principal component analysis for all samples indicated that it had a good biological repetition, and the quality of selected data was reliable (Supplementary Materials Figure S1). A hierarchical clustering tree for all samples was drawn to identify the outliers in the samples; the results showed that there was no outlier in the samples, and that all samples could be used in our analysis (Figure 1). After removing the genes with $\mathrm{SD}<0.5$ between samples, we finally retained 7689 eligible protein-coding genes for subsequent analysis.

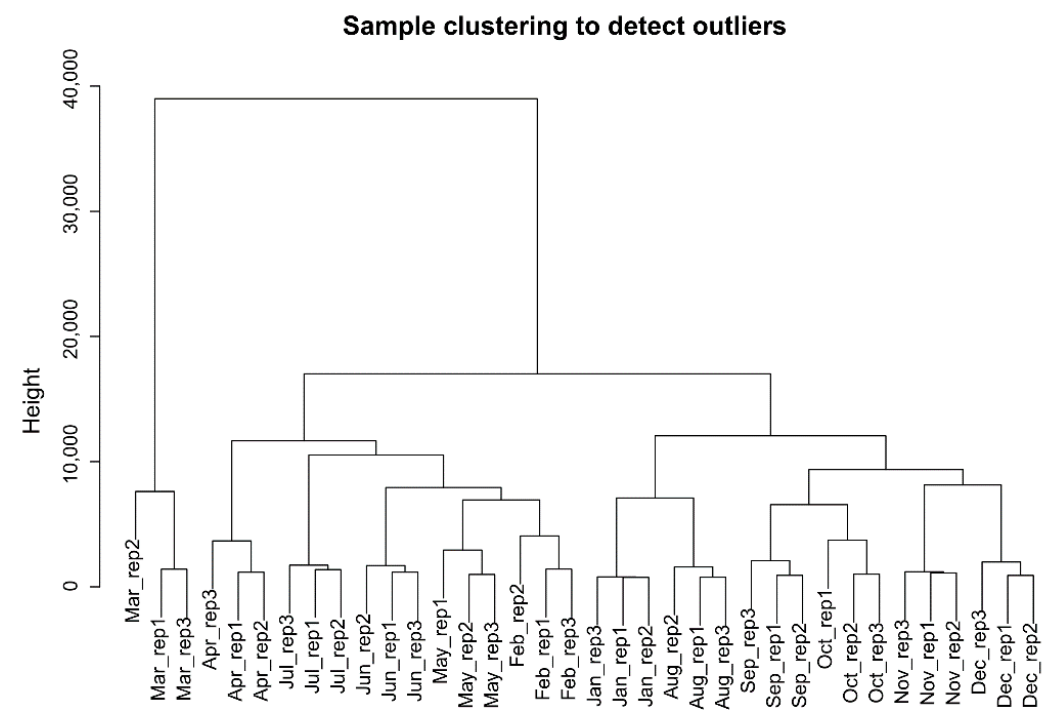

Figure 1. Hierarchical clustering information of samples.

\subsection{Construction of the Weighted Gene Coexpression Network}

To obtain a coexpression network, we used different soft-thresholding power $\beta$ values, i.e., from 1 to 20 , to calculate network structures. When $\beta$ was set at 9 , the scale-free network fitting index reached 0.85 (Figure 2A) and the connectivity between genes in the network was relatively high, which met the scale-free network distribution (Figure 2B). Then, the dynamic hybrid-cutting method was used to cluster genes into modules, and similar modules were merged by setting the MEDissThres cutting line to 0.25 (i.e., the models with $75 \%$ of eigengenes similarity were merged) (Figure $3 \mathrm{~A}$ ). $\mathrm{ME}_{\text {pink }}$ were merged in $\mathrm{ME}_{\text {magenta, }}$, in addition, $\mathrm{ME}_{\text {blue }}$ and $\mathrm{ME}_{\text {red }}$ were merged in $\mathrm{ME}_{\text {turquoise }}$. Finally, ten modules were obtained (Figure 3B). The number and proportion of genes corresponding to the ten modules were calculated and are visualized in Figure 3C. Through the adjacency heatmap of the relationship for each model (Figure 3D), we found that the coexpression relationship of genes from the same module was strong and the ten modules were relatively independent from each other. All corresponding genes in each module can be viewed in Supplementary Materials Table S2. 
A

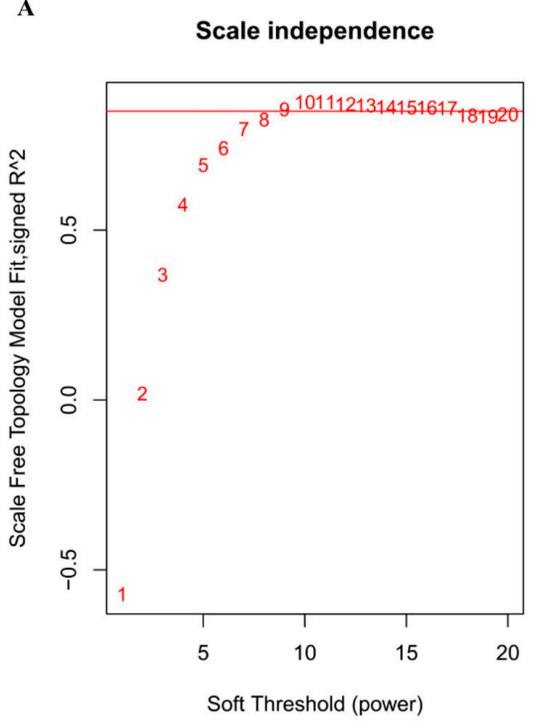

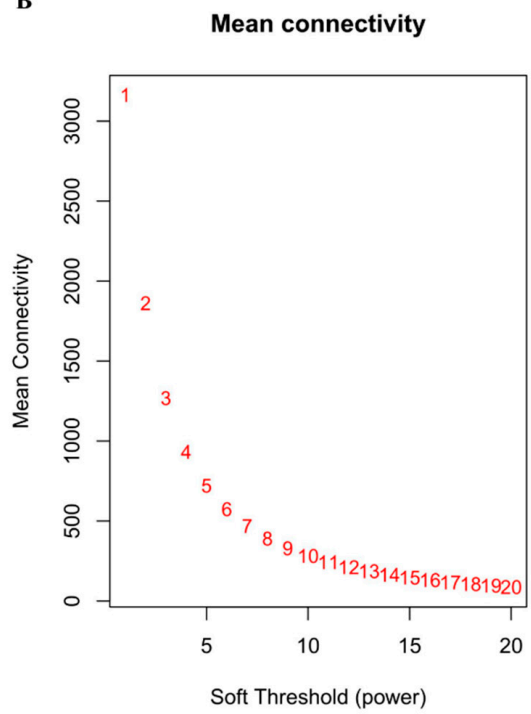

Figure 2. The determination of soft thresholding power. (A) is a scale-free fitting index (y-axis) responding to various soft-thresholding powers (x-axis). (B) represents the mean connectivity (y-axis) of different soft-thresholding power (x-axis). The approximate scale-free topology can be obtained at the soft-thresholding power of 9 .

A

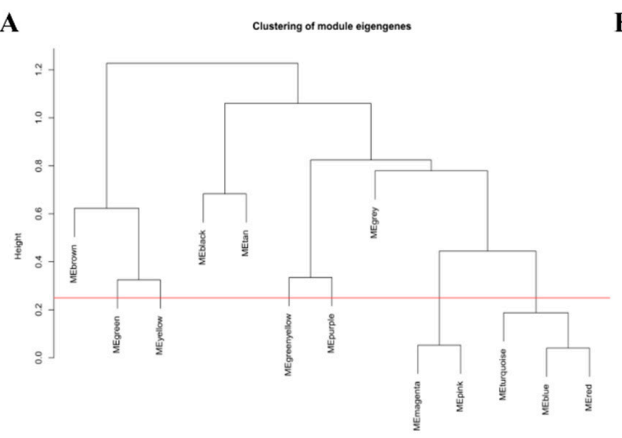

C

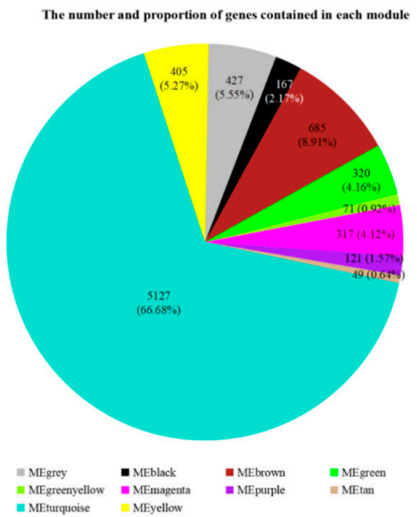

B

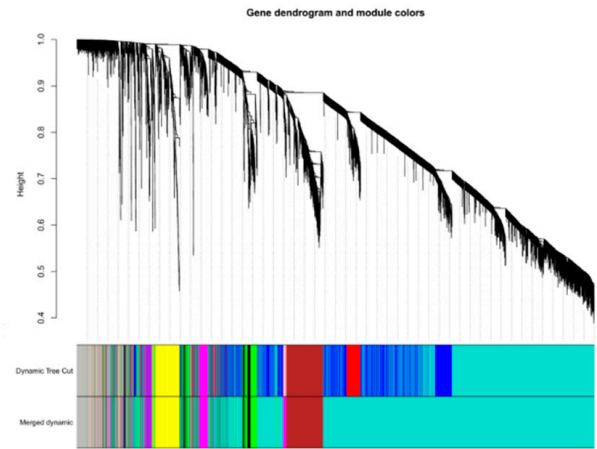

D
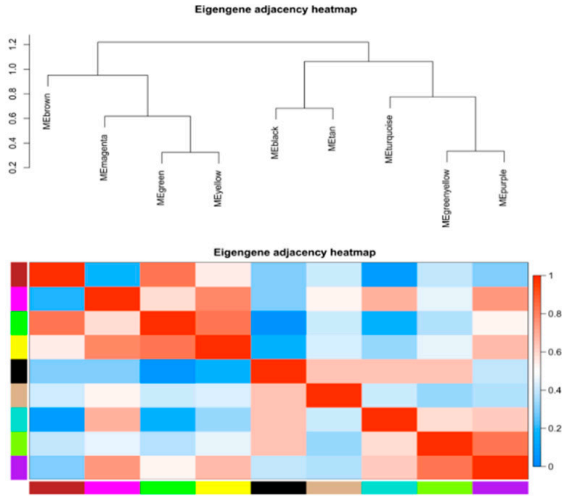

Figure 3. Identification of coexpression modules by weighted gene coexpression network analysis. (A) The cluster dendrogram of gene modules eigengenes. Modules with similar expression patterns need to be merged and the red line is the merging threshold. (B) The gene clustering dendrogram was obtained according to hierarchic clustering of adjacency-based dissimilarity. The color blocks below the tree graph represent coexpression modules recognized by the dynamic hybrid-cutting method. The genes in grey module were not classified into any coexpression modules. (C) The number and proportion of genes contained in each module. (D) The adjacency heatmap of eigengene. Above is the module clustering tree, and below is the corresponding module clustering heatmap. Red represents strong correlation and blue represents weak correlation. 


\subsection{Key Modules Related to Periodic Development of HFs}

To identify these modules related to HFC, the module-trait correlation (Figure 4) and GS values in four stages (Supplementary Materials Figure S2) were calculated. Six out of ten modules were identified to be closely related to the HFC in cashmere goats. The $\mathrm{ME}_{\text {greenyellow }}\left(\mathrm{cor}=0.63, p=4 \times 10^{-5}\right)$ and $\mathrm{ME}_{\text {purple }}\left(\mathrm{cor}=0.71, p=1 \times 10^{-6}\right)$ were positively correlated with HFs development in anagen (Figure 4 and Supplementary Materials Figure $\mathrm{S} 2 \mathrm{~A}$ ). $\mathrm{ME}_{\text {black }}$ was positively related with HFs development in catagen (cor $=0.69$, $p=3 \times 10^{-6}$ ) (Figure 4 and Supplementary Materials Figure S2B). $\mathrm{ME}_{\tan }$ was positively related with HFs development in telogen $\left(\mathrm{cor}=0.66, p=1 \times 10^{-5}\right)$, while $\mathrm{ME}_{\text {greenyellow }}$ was negatively correlation in telogen ( $c o r=-0.71, p=1 \times 10^{-6}$ ) (Figure 4 and Supplementary Materials Figure S2C). ME brown was positively related with HFs development in the latetelogen ( cor $\left.=0.87, p=5 \times 10^{-12}\right)$, but $\mathrm{ME}_{\text {magenta }}$ was negatively correlation in late-telogen $\left(\right.$ cor $\left.=-0.77, p=5 \times 10^{-8}\right)$ (Figure 4 and Supplementary Materials Figure S2D).

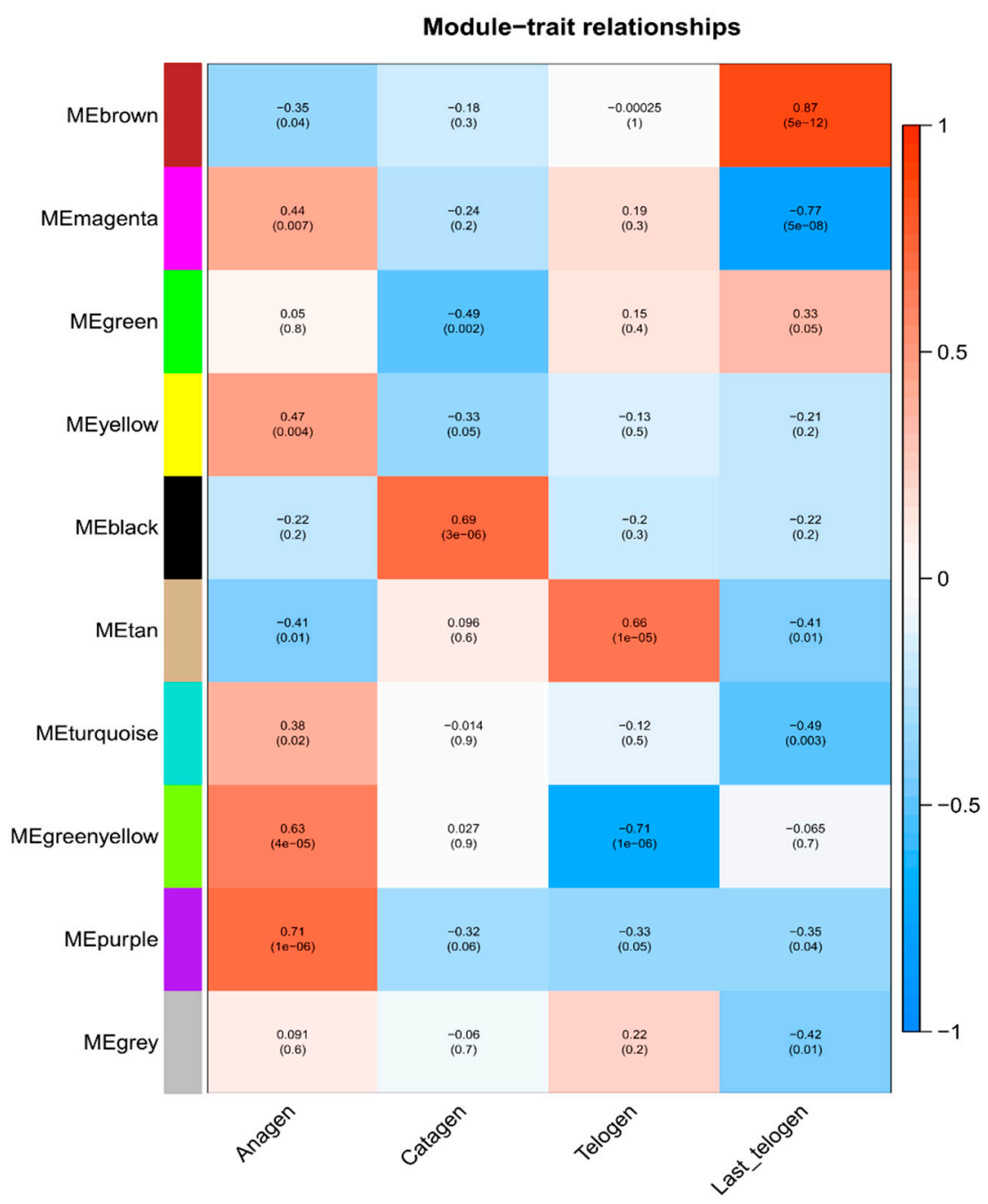

Figure 4. Heatmap of the correlation between module and hair follicle cycle features. The Numbers on the top of the block represent the correlation, the $p$ values on the bottom. Red means positive correlation, blue means negative correlation.

\subsection{Gene Enrichment Analysis from Key Modules}

To explore the molecular functions and biological pathways of genes in key modules significantly associated with the periodic development of the HF, we performed GO enrichment analysis for the six module genes mentioned above. The genes of $\mathrm{ME}_{\text {greenyellow }}$ and $\mathrm{ME}_{\text {black }}$ were mainly involved in cytoskeleton, supramolecular complex and intermediate 
filament. The $\mathrm{ME}_{\text {tan }}$ genes were related to fatty acid biosynthetic process and response to corticotropin-releasing hormone. The $\mathrm{ME}_{\text {purple }}$ genes were involved in extracellular matrix, extracellular region and collagen trimer. The $\mathrm{ME}_{\text {brown }}$ genes were enriched in intracellular, organelle, ribosome and mitochondrion, and participated in metabolic process. The $\mathrm{ME}_{\text {magenta }}$ genes were enriched in the extracellular and membrane, and related to regulation of response to stimulus (Supplementary Materials Figure S3 and Supplementary Materials Table S3).

KEGG pathway analysis showed that the $\mathrm{ME}_{\text {greenyellow }}$ and $\mathrm{ME}_{\text {purple }}$ genes related to anagen period were enriched in complement and coagulation cascades and PI3K-Akt signaling pathway, focal adhesion and extracellular matrixc (ECM)-receptor interaction (Table 1), respectively. The significant pathway in $\mathrm{ME}_{\text {black }}$ related to Catagen was estrogen signaling pathway. The genes of $\mathrm{ME}_{\text {tan }}$ and $\mathrm{ME}_{\text {greenyellow }}$ related to telogen period were enriched in glycerolipid metabolism, fat digestion and absorption, and complement and coagulation cascades, respectively. The genes of $\mathrm{ME}_{\text {brown }}$ and $\mathrm{ME}_{\text {magenta }}$ related to lasttelogen were focused on ribosome and infection (Table 1), respectively.

Table 1. KEGG pathways in coexpression modules.

\begin{tabular}{|c|c|c|c|c|}
\hline Modules & Terms & Adj-p-Value & Gene Counts & Genes \\
\hline $\mathrm{ME}_{\text {greenyellow }}$ & Complement and coagulation cascades & 0.004 & 4 & $\begin{array}{l}\text { C1QC; C1QB; ENSCHIG00000015928; } \\
\text { ENSCHIG00000021894 }\end{array}$ \\
\hline \multirow{4}{*}{$\mathrm{ME}_{\text {purple }}$} & ECM-receptor interaction & 0.002 & 5 & COL6A2; COL1A2; THBS3; CHAD; COL1A1 \\
\hline & PI3K-Akt signaling pathway & 0.009 & 7 & $\begin{array}{l}\text { THEM4; CHAD; THBS3; CREB3L1; COL1A2; } \\
\text { COL1A1; COL6A2 }\end{array}$ \\
\hline & Focal adhesion & 0.016 & 5 & COL6A2; COL1A2; THBS3; CHAD; COL1A1 \\
\hline & Human papillomavirus infection & 0.022 & 6 & $\begin{array}{l}\text { CHAD; THBS3; CREB3L1; COL1A2; COL1A1; } \\
\text { COL6A2 }\end{array}$ \\
\hline \multirow{2}{*}{$\mathrm{ME}_{\text {black }}$} & Staphylococcus aureus infection & $5.24 \times 10^{-9}$ & 10 & $\begin{array}{l}\text { KRT36; KRT35; KRT28; KRT27; C5AR1; } \\
\text { ENSCHIG00000011715; ENSCHIG00000017849; } \\
\text { ENSCHIG00000021923; ENSCHIG00000022158; } \\
\text { ENSCHIG00000025510 }\end{array}$ \\
\hline & Estrogen signaling pathway & $8.36 \times 10^{-7}$ & 10 & $\begin{array}{l}\text { KRT36; KRT35; KRT28; KRT27; ADCY5; } \\
\text { ENSCHIG00000011715; ENSCHIG00000012764; } \\
\text { ENSCHIG00000017849; ENSCHIG00000021923; } \\
\text { ENSCHIG00000025510 }\end{array}$ \\
\hline \multirow[t]{2}{*}{$\mathrm{ME}_{\tan }$} & Glycerolipid metabolism & $9.82 \times 10^{-5}$ & 5 & $\begin{array}{l}\text { GLYCTK; ENSCHIG00000010141; } \\
\text { ENSCHIG00000012088; ENSCHIG00000015313; } \\
\text { ENSCHIG00000017465 }\end{array}$ \\
\hline & Fat digestion and absorption & 0.001 & 4 & $\begin{array}{l}\text { ENSCHIG00000010141; ENSCHIG00000012088; } \\
\text { ENSCHIG00000015313; ENSCHIG00000017465 }\end{array}$ \\
\hline \multirow{3}{*}{$\mathrm{ME}_{\text {brown }}$} & Ribosome & $2.00 \times 10^{-7}$ & 22 & $\begin{array}{l}\text { RPL36; MRPS15; MRPL27; MRPL24; MRPL21; } \\
\text { MRPL14; ENSCHIG00000000917; } \\
\text { ENSCHIG00000000315; ENSCHIG00000003454; } \\
\text { ENSCHIG00000005169; ENSCHIG00000006564; } \\
\text { ENSCHIG00000007457; ENSCHIG00000007926; } \\
\text { ENSCHIG00000009094; ENSCHIG00000010382; } \\
\text { ENSCHIG00000010444; ENSCHIG00000011183; } \\
\text { ENSCHIG00000011261; ENSCHIG00000011972; } \\
\text { ENSCHIG00000013535; ENSCHIG00000019224; } \\
\text { ENSCHIG00000023286 }\end{array}$ \\
\hline & Oxidative phosphorylation & 0.004 & 14 & $\begin{array}{l}\text { SDHC; NDUFS5; NDUFB9; NDUFB7; } \\
\text { NDUFB10; NDUFAB1; COX7A2L; COX17; } \\
\text { ATP6VOC; ENSCHIG00000003884; } \\
\text { ENSCHIG00000008372; ENSCHIG00000008931; } \\
\text { ENSCHIG00000012976; ENSCHIG00000015565 }\end{array}$ \\
\hline & $\begin{array}{l}\text { Nonalcoholic fatty liver disease } \\
\text { (NAFLD) }\end{array}$ & 0.009 & 14 & $\begin{array}{l}\text { SDHC; NR1H3; NDUFS5; NDUFB9; NDUFB7; } \\
\text { NDUFB10; NDUFAB1; GSK3A; COX7A2L; } \\
\text { CEBPA; ENSCHIG00000003884; } \\
\text { ENSCHIG00000008372; ENSCHIG00000012976; } \\
\text { ENSCHIG00000015565 }\end{array}$ \\
\hline
\end{tabular}


Table 1. Cont.

\begin{tabular}{|c|c|c|c|c|}
\hline Modules & Terms & Adj- $p$-Value & Gene Counts & Genes \\
\hline \multirow{6}{*}{$\mathrm{ME}_{\text {magenta }}$} & Antigen processing and presentation & 0.001 & 8 & $\begin{array}{l}\text { PDIA3; CTSL; ENSCHIG00000008848; } \\
\text { ENSCHIG00000009614; ENSCHIG00000012657; } \\
\text { ENSCHIG00000018922; ENSCHIG00000019468; } \\
\text { ENSCHIG00000024246 }\end{array}$ \\
\hline & Epstein-Barr virus infection & 0.001 & 13 & $\begin{array}{l}\text { PDIA3; NFKBIA; ICAM1; CD19; CCND3; AKT1; } \\
\text { ENSCHIG00000008848; ENSCHIG00000009614; } \\
\text { ENSCHIG00000012657; ENSCHIG00000018922; } \\
\text { ENSCHIG00000019468; ENSCHIG00000019897; } \\
\text { ENSCHIG00000024246 }\end{array}$ \\
\hline & $\begin{array}{l}\text { Human immunodeficiency virus } 1 \\
\text { infection }\end{array}$ & 0.012 & 12 & $\begin{array}{l}\text { TNFRSF1A; STING1; PDIA3; NFKBIA; CFL1; } \\
\text { AKT1; ENSCHIG00000008848; } \\
\text { ENSCHIG00000009614; ENSCHIG00000012657; } \\
\text { ENSCHIG00000018922; ENSCHIG00000019468; } \\
\text { ENSCHIG00000024246 }\end{array}$ \\
\hline & $\begin{array}{l}\text { Human T-cell leukemia virus } 1 \\
\text { infection }\end{array}$ & 0.016 & 12 & $\begin{array}{l}\text { TNFRSF1A; NFKBIA; ICAM1; CCND3; AKT1; } \\
\text { ENSCHIG00000008848; ENSCHIG00000009614; } \\
\text { ENSCHIG00000012562; ENSCHIG00000012657; } \\
\text { ENSCHIG00000018922; ENSCHIG00000019468; } \\
\text { ENSCHIG00000024246 }\end{array}$ \\
\hline & Human cytomegalovirus infection & 0.021 & 12 & $\begin{array}{l}\text { TNFRSF1A; STING1; PDIA3; NFKBIA; AKT1; } \\
\text { ENSCHIG00000008848; ENSCHIG00000009614; } \\
\text { ENSCHIG00000011782; ENSCHIG00000012657; } \\
\text { ENSCHIG00000018922; ENSCHIG00000019468; } \\
\text { ENSCHIG00000024246 }\end{array}$ \\
\hline & Fluid shear stress and atherosclerosis & 0.035 & 9 & $\begin{array}{l}\text { TNFRSF1A; PECAM1; ICAM1; CTSL; AKT1; } \\
\text { ACVR2B; ENSCHIG00000008471; } \\
\text { ENSCHIG00000026143; ENSCHIG00000026491 }\end{array}$ \\
\hline
\end{tabular}

\subsection{Hub Genes Closely Related to Different Stages of Hair Follicle Development}

We used two methods to identify hub genes correlated with the periodic development of HFs. Based on MM and GS values of the genes in each of the key modules to select the hub genes, $|\mathrm{GS}|>0.2,|\mathrm{MM}|>0.9$ and $p$.weighted $<0.01$ were used as the identification criteria. As a result, 11, 14, 20, 8, 260 and 21 genes were obtained from $\mathrm{ME}_{\text {greenyellow, }}$ $\mathrm{ME}_{\text {purple }}, \mathrm{ME}_{\text {black }}, \mathrm{ME}_{\text {tan }}, \mathrm{ME}_{\text {brown }}$ and $\mathrm{ME}_{\text {magenta }}$, respectively (Supplementary Materials Table S4). In addition, MCC algorithm in cytoHubba plugin from Cytoscape software were used to screen hub candidates (Supplementary Materials Table S5) [48]. Combining these two methods, finally, a total of 38 hub genes were found: six in $\mathrm{ME}_{\text {greenyellow, }}$ seven in $\mathrm{ME}_{\text {purple, }}$ eight in $\mathrm{ME}_{\text {black}}$, six in $\mathrm{ME}_{\text {tan, }}$, ten in $\mathrm{ME}_{\text {brown }}$ and one in $\mathrm{ME}_{\text {magenta }}$ (Supplementary Materials Figure S4).

\subsection{Verification of Hub Genes by DEGs Analysis}

To verify the relationship between hub genes and HFs development, we detected the expression of hub genes by DEGs analysis based on the filtered 13,910 genes at a given period compared with other periods. The DEGs analysis results were shown in Figure 5A-D. The numbers of DEGs in anagen vs. others, catagen vs. others, telogen vs. others and last-telogen vs. others were respectively 759 (up-regulated 523, downregulated 236), 167 (up-regulated 68, down-regulated 99), 231 (up-regulated 26, downregulated 205) and 5903 (up-regulated 2215, down-regulated 3688). Using the online software Venny to overlap hub genes and DEGs, it showed that 20 genes out of 38 hub genes were overlapped to up-regulated DEGs including five hub genes in anagen (Figure 5E), four hub genes in catagen (Figure 5F), two hub genes in telogen (Figure 5G) and nine hub genes in last-telogen (Figure $5 \mathrm{H}$ ). Six genes out of 38 hub genes were overlapped to downregulated DEGs including five hub genes (ENSCHIG00000011548, ENSCHIG00000014533, ENSCHIG00000015017, ENSCHIG00000010344 and ENSCHIG00000000533) in telogen and one hub gene (ENSCHIG00000009953) in last-telogen. In four stages, the coexpression network of hub genes interacting with multiple genes were visualized (Figure 6A-D), 
which suggested the importance of these hub genes in the regulation. Twelve genes in all differential expression hub genes have been annotated, including four genes (COL1A1, C1QTNF6, COL1A2 and AQP3) in anagen, two genes (KRTAP3-1 and KRTAP11-1) in catagen, one gene $(F A 2 H)$ in telogen and five genes (NDUFS5, DERL2, MRPL14, ANTKMT and $X A B 2)$ in last-telogen. These differential hub genes involved in the process and pathways related to cyclic development of hair follicle by coexpression regulation in different modules. To understand the dynamic expression of these 12 annotated genes in the HFC of cashmere goats, their expression levels were visualized in Figure 7.

A

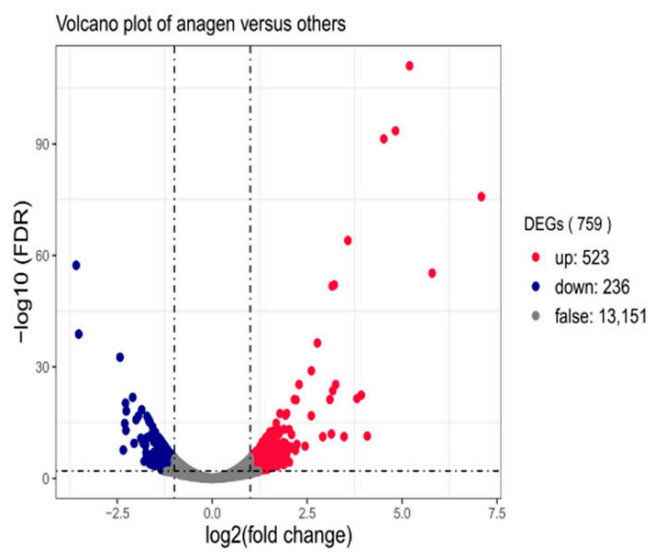

B

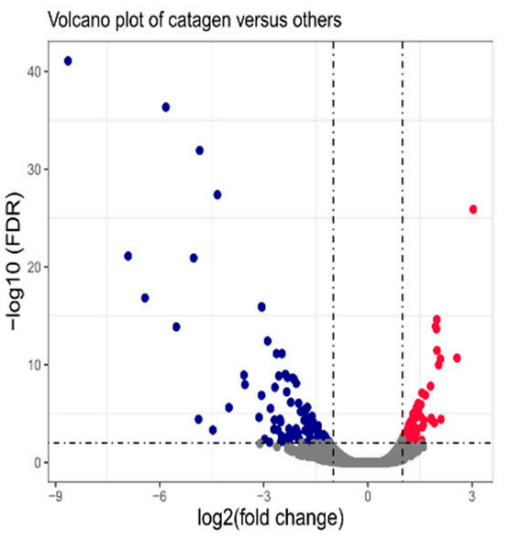

C

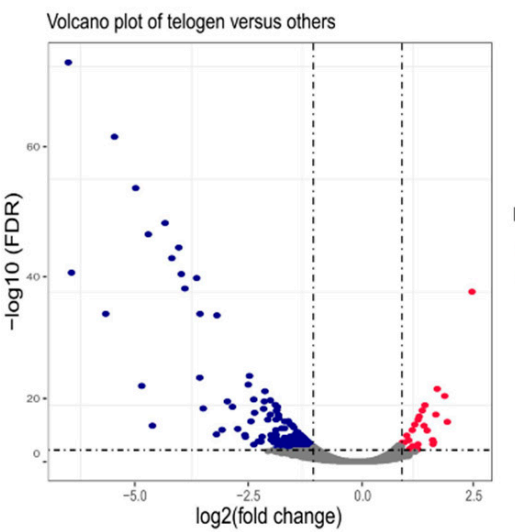

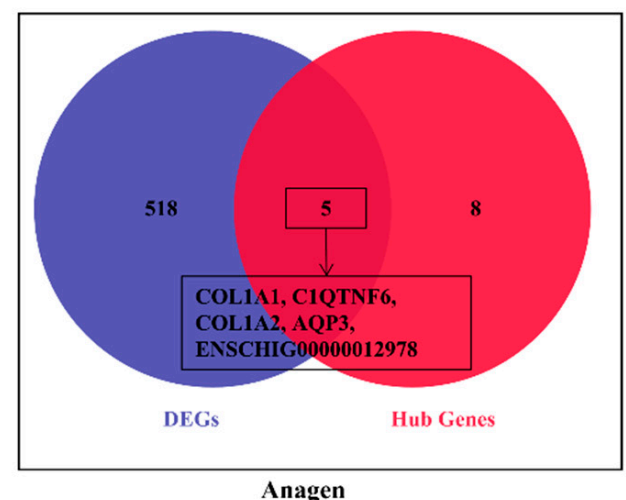

F

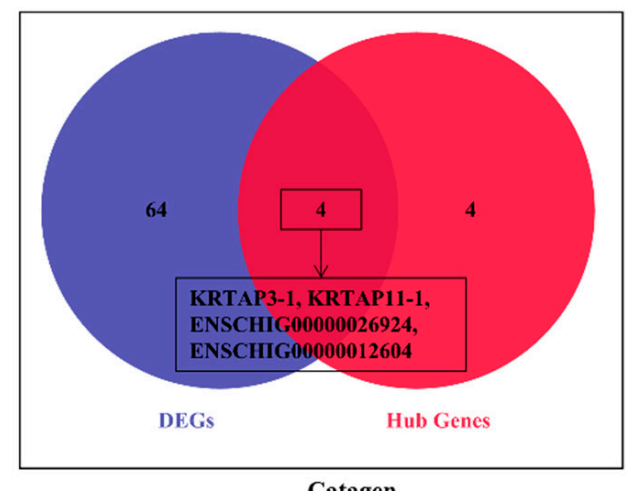

Catagen

G

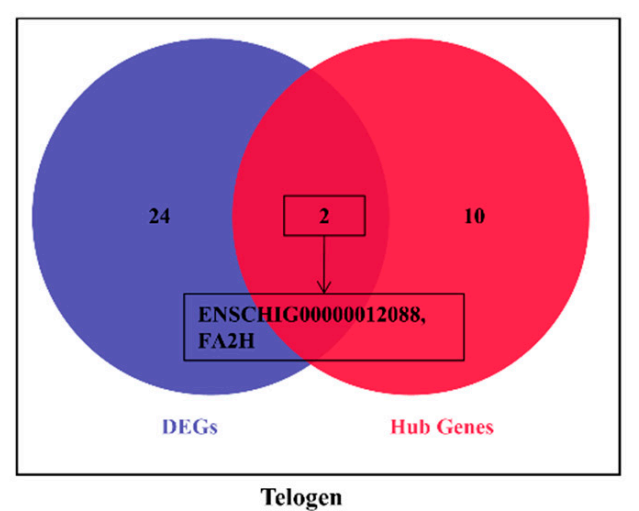

Figure 5. Cont. 
D

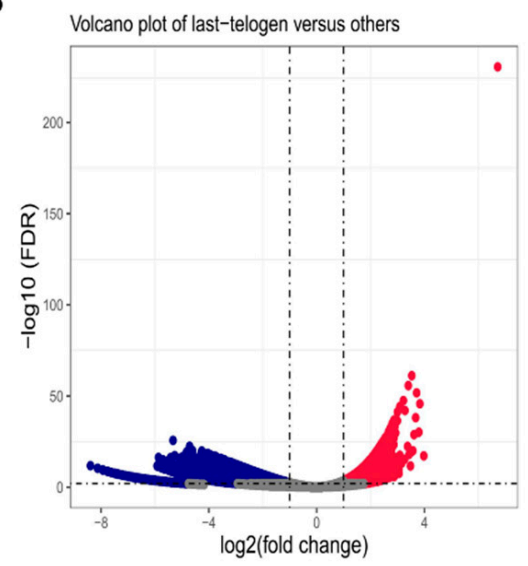

$\mathbf{H}$

$\operatorname{DEGs}(5,903)$

up: 2,215

- down: 3,688

- false: 8,007

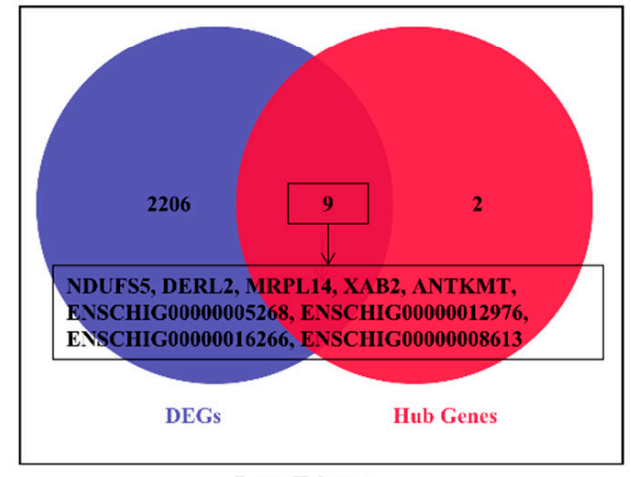

Late-Telogen

Figure 5. Differential expression hub genes related to different stages of hair follicle regeneration. The results of differential expression genes analysis in (A) anagen (B) catagen, (C) telogen and (D) late-telogen compared with nonself stages. Overlapping results of up-regulated differential expression genes and hub genes in (E) anagen, (F) catagen, $(\mathbf{G})$ telogen and (H) late-telogen.
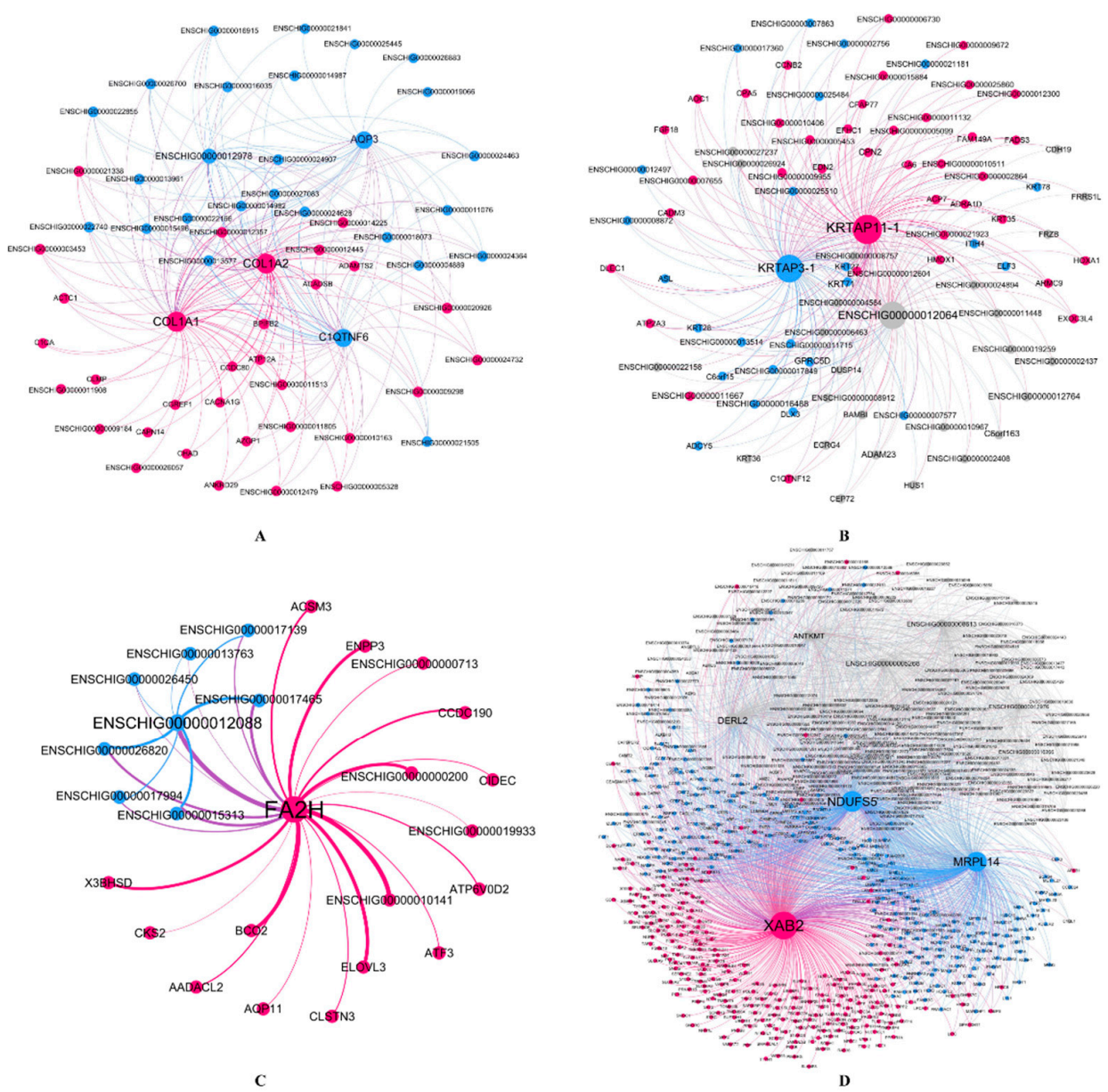

Figure 6. Visualization of coexpression network between hub genes with interaction genes in four stages. (A) anagen, (B) catagen, (C) telogen and (D) late-telogen. The size of the circle represents the degree values of the adjacency genes in the network from WGCNA. Nodes and edges were colored based on Gephi modularity class to classify individual nodes into network communities. The thickness of the edge represents the strength of the interaction between genes, and the thicker the line, the stronger the interaction. 


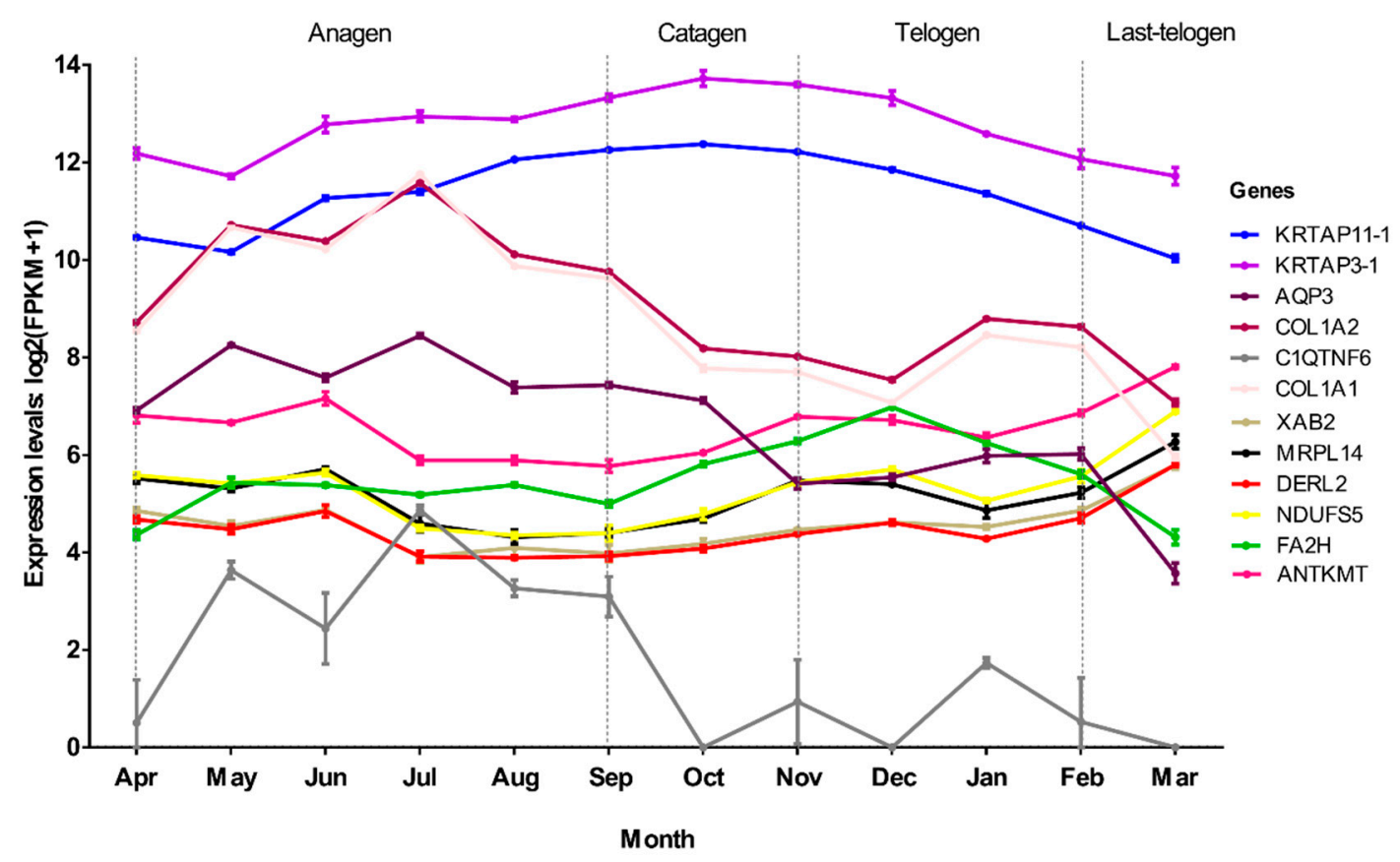

Figure 7. Line chart of the expression changes of 12 hub genes throughout the hair follicle cycle of cashmere goats.

\section{Discussion}

Hair follicles of cashmere goat undergo annual cyclic changes. The economic value and reference value for research on human hair loss have led researchers to focus on the molecular mechanism of HF regeneration in cashmere goats. Though some genes and signals have been found, precise knowledge is still lacking, due to the polygenes and multiple pathways involved. In this study, WGCNA was used to find hub genes and pathways in different periodical development phases of HFs based RNA-seq data from skins tissues of Inner Mongolia cashmere goats.

Sample hierarchical cluster analysis were performed by WGCNA based on all gene expression levels over 12 months. The results showed that there were three obvious clusters: Mar., Aug to Jan, and Feb to Jul except for Mar (Figure 1). According to the growth cycle of HF, it mainly included three stages: anagen, catagen, and telogen. It seemed that the categories could correspond to the stages, but we found that the gene expression changes of Jan. and Aug., Feb. and May were clustered together (Figure 1), respectively. In fact, for the Inner Mongolia cashmere goat, the cashmere shed in Apr. when it was just the month of collecting cashmere and hair follicle started to grow again until to Sept.

Thus, combined the morphological changes of hair follicle [18], Jan. and Aug., Feb. and May should not be in same stages, respectively. However, the periodical development of hair follicle was induced by the cyclical fluctuation of gene expression, and their expression patterns between different months (Feb. and May, Jan. and Aug.) may be similar and clustered together. For Mar., it was a transition stage from the telogen to the anagen and it was furthest from other months based on the cluster analysis, so it was specified as last-telogen. Finally, we divided the development of HFs into four stages: anagen (April-September), catagen (October and November), telogen (December-February), lasttelogen (March).

After constructing the weighted gene coexpression network modules and correlating with the HF development stages, six key modules were found. $\mathrm{ME}_{\text {purple }}$ and $M E_{\text {greenyellow }}$ in anagen focused on ECM-receptor interaction, PI3K-Akt signaling pathway, complement and coagulation cascades (Table 1). Genes from $\mathrm{ME}_{\text {black }}$ in catagen were associated with epithelial cell differentiation and estrogen signaling pathway (Supplementary Materials Figure S3, Table 1). Genes from $\mathrm{ME}_{\tan }$ and $\mathrm{ME}_{\text {greenyellow }}$ in telogen were related to the fatty 
metabolism and the composition of supramolecular fiber, respectively (Supplementary Materials Figure S3, Table 1). Genes from metabolism-related $\mathrm{ME}_{\text {brown }}$ and stimulus-related $\mathrm{ME}_{\text {magenta }}$ the immune response had the higher correlation with late-telogen (Supplementary Materials Figure S3, Table 1). In these models, 12 annotated hub genes were found by coexpression regulation involving in the periodic development of hair follicle (Figure 6).

In anagen, COL1A1, C1QTNF6, COL1A2 and AQP3 were identified as hub genes. COL1A1 and COL1A2 encode the proalpha1 and two chains of type I collagen which is the major protein of the extracellular matrix (ECM) [55-57]. ECM widely exists in dermal sheath and dermal papilla (DP) in anagen [58-60], diminishes during catagen, and is minimal in the telogen follicle [61]. The interaction between DP and ECM plays an important role in HF development. The ECM type I collagen can enhance DP cell aggregation through its effect on cell adhesion and motility, which is essential in hair regeneration $[62,63]$. In our study, we found that COL1A1 and COL1A2 were highly expressed in anagen especially July when the follicle was in vigorous (Figure 7). Moreover, COL1A1 and COL1A2 participated not only in ECM-receptor interaction, but also in focal adhesion and PI3K-Akt signaling pathway (Table 1). Focal adhesions can engage with the surrounding ECM [64] and relate to the migration of HF stem cells towards the bulb region [65]. The effect of the PI3K/AKT signaling pathway on the regeneration of hair follicles has also been reported [66]. All these results prove that COL1A1 and COL1A2 are essential for regeneration of cashmere hair and can be used as important candidate genes for in-depth study of its function. $A Q P 3$ is an aquaporin coding gene, which is highly expressed in epidermal keratinocytes [67-69]. It plays a decisive role in epidermal proliferation and skin damage repair by mediating the transport of water and glycerol $[6,70]$. AQP3 can participate in the migration and proliferation of keratinocytes [70], and provide glycerol for phospholipase D2 (PLD2) to synthesize phosphatidylglycerol (PG), negative feedback inhibits keratinocyte proliferation and promote keratinocyte differentiation [71,72]. Our research showed that $A Q P 3$ was highly expressed in anagen (Figure 7) and interacted with COL1A1 and COL1A2. Recently, AQPs was clustered in the group of seasonal rhythm genes in cashmere goat skin [73], which indicated these genes played an important role in maintain the specific rhythm of the HF growth.

In catagen, KRTAP3-1 and KRTAP11-1 were identified as hub genes. KRTAP3-1 and KRTAP11-1 belong to keratin-associated proteins (KRTAPs) family. KRTAPs are the main structural protein molecules of hair fibers. A large number of studies have shown that KRTAPs are highly expressed in the cortex area of hair fibers and play a key role in the physical properties of hairs [74-76]. The dynamic change of KRTAPs throughout HFC affects the growth of hair follicle and hair shaft [74,77]. It was showed KRTAP11-1 was mainly expressed in catagen and telogen and could interact with other genes to regulate the HFs development [78]. KRTAP11-1 not only promoted the expression of catagen-inducing factors (BMP2 and TGF $\beta 1$ ), but also inhibited the expression of growth-activator (LEF1) [78]. It was reported KRTAP3-1 expressed highly in September than February when only comparing these two months in Shanbei cashmere goat [79]. In this study, we found that both KRTAP11-1 and KRTAP3-1 were highly expressed throughout HFC and reached to the peak in October (catagen) (Figure 7). If only comparing September and February, it had similar results for these two genes expression.

The telogen can be divided into early-refractory and last-competent stages. Conventionally, the telogen is merely an idle waiting period for HFs to enter the anagen of proliferation and differentiation. But new study argues that the telogen is a complicated stage in which HFs are biologically active [80]. During refractory telogen stage, HFs are insensitive to response anagen-inducing stimuli [81]. In this study, we only found one hub genes, fatty acid 2-hydroxylase $(F A 2 H)$, was highly expressed in cashmere skin in the telogen. $F A 2 H$ is mainly participates in the biological oxidation of fatty acids (Supplementary Materials Table S3) and the synthesis of 2-hydroxylated sphingolipids, which is believed to play a role in the formation of epidermal barrier [82-85]. Previous study has shown that $F A 2 H$ in mouse is only expressed in sebaceous glands of skin, but the absence of $F A 2 H$ can 
delay hair generation with hair loss in telogen period [83]. This suggests that $F A 2 H$ plays important roles in maintaining the hair follicle homeostasis in the early telogen period.

Indeed, the growth traits of HFs in last-telogen are the lowest value in histology throughout HFC $[3,7,18]$, but some people thought last-telogen is the master-switch that controls HFC by retaining hair fibers with minimal energy expenditure and responding to a variety of stimuli to launch a new regeneration cycle $[80,86]$. In this study, genes in $\mathrm{ME}_{\text {brown }}$ and $\mathrm{ME}_{\text {magenta }}$ associated with last-telogen were involved in metabolic process and stimulus response and immunity, respectively (Table 1, Supplementary Materials Tables S3 and S4). In addition, increasing research showed that mitochondria could determine the differentiation and proliferation of hair cell upon injury by regulating energy metabolism [87,88], regulate skin aging and hair loss [89]. Mitochondria metabolic disorders can lead to hair and skin abnormalities [90]. Five hub genes were found in last-telogen, i.e., NDUFS5, DERL2, MRPL14, ANTKMT and XAB2. Among these, DERL2 and XAB24, NDUFS5 and MRLP1 had a similar expression profile across the year (Figure 7). NDUFS5 and MRPL14 participated in the synthesis of mitochondrial protein complex and ribosomal subunits. DERL2, ANTKMT and XAB2 were mainly involved in the metabolic process. According to coexpression network, these hub genes interacted with many of other genes to form a large and complex signaling network (Figure 6D). They might be crucial to conserving energy and initiating new cycles during last-telogen. Further research is needed to fully uncover the magic of last-telogen.

\section{Conclusions}

In this study, WGCNA was used to construct a gene-weighted coexpression network to explore key gene modules and hub genes closely related to the development of HFC in cashmere goats. Six key modules were identified, and genes in models were enriched using well-known biological processes or pathways, such as epithelial cell differentiation, ECM-receptor interaction, and the PI3K-Akt signaling pathway. Moreover, we also found metabolism process, response, and immunity related pathways in last-telogen. Twelve hub genes with significant expression changes in different development stages of HFs were selected as candidate marks. All of these findings help us better understand the internal mechanism of hair follicle growth and development in cashmere goats. In addition, these hub genes might be a medium to artificially regulate and control the production of cashmere.

Supplementary Materials: The following are available online at https:/ /www.mdpi.com/2073-442 5/12/2/180/s1, Figure S1: PCA analysis results of 36 samples. Figure S2: The histogram of average gene significance (GS) in the modules associated with the different stages of the hair follicle cycle. (A-D) represented the GS values in anagen, catagen, telogen and last-telogen period, respectively. Figure S3: GO enrichment analysis results of each module genes. Figure S4: Screening of key genes in the network. The blue represents hub genes exported by CytoHubba, the red represents hub genes obtained by $|\mathrm{GS}|>0.2$ and $|\mathrm{MM}|>0.9$ criterion, and the intersection represents the common hub genes screened by both methods. Table S1: Alignment rates of effective RNA-seq sequences on the reference genome. Table S2: The list of genes contained in each module. Table S3: Go functional annotation of genes from the modules significantly related to the cyclic development of hair follicle. Table S4: The hub candidates table of GS and MM values form WGCNA. Table S5: The top ten hub candidates with MCC values form CytoHubba.

Author Contributions: Conceptualization, J.W., J.S. and C.J.; Data curation, J.W.; Formal analysis, J.W. and C.J.; Funding acquisition, C.J.; Methodology, J.W.; Resources, J.W. and C.M.; Software, J.W.; Supervision, C.J.; Validation, C.J.; Visualization, J.W. and C.J.; Writing—original draft, J.W. and C.J.; Writing-review \& editing, J.S., C.M., X.L., X.C., C.L., X.W., S.-H.W. and C.J. All authors have read and agreed to the published version of the manuscript.

Funding: This research was funded by National Natural Science Foundation of China (No.31501990).

Institutional Review Board Statement: Ethical review and approval were waived for this study, due to our study gathered data from the website. 
Informed Consent Statement: Not applicable.

Data Availability Statement: All data analyzed during this study are available in the website (https: / / www.ncbi.nlm.nih.gov/sra/?term=SRP145408).

Conflicts of Interest: The authors declare no conflict of interest.

\section{References}

1. Erdoğan, B. Anatomy and Physiology of Hair. Hair Scalp Disord. 2017, 13. [CrossRef]

2. Paus, R.; Foitzik, K. In search of the "hair cycle clock": A guided tour. Differentiation 2004, 72, 489-511. [CrossRef] [PubMed]

3. Stenn, K.S.; Paus, R. Controls of Hair Follicle Cycling. Physiol. Rev. 2001, 81, 449-494. [CrossRef] [PubMed]

4. Mangelsdorf, S.; Vergou, T.; Sterry, W.; Lademann, J.; Patzelt, A. Comparative study of hair follicle morphology in eight mammalian species and humans. Skin research and technology. Off. J. Int. Soc. Bioeng. Ski. 2014, 20, 147-154.

5. Ibraheem, M.; Galbraith, H.; Scaife, J.; Ewen, S. Growth of secondary hair follicles of the Cashmere goat in vitro and their response to prolactin and melatonin. J. Anat. 1994, 185, 135-142.

6. Debbarma, S.; Ashutosh; Saini, S.; Gowda, S.B. Seasonal effect in expression of AQP1, AQP3 and AQP5 in skin of Murrah buffaloes. J. Biol. 2020, 93, 102727. [CrossRef]

7. Liu, B.; Gao, F.; Guo, J.; Wu, D.; Hao, B.; Li, Y.; Zhao, C. A Microarray-Based Analysis Reveals that a Short Photoperiod Promotes Hair Growth in the Arbas Cashmere Goat. PLoS ONE 2016, 11, e0147124. [CrossRef]

8. Kerkhoff, K.; Cescutti, G.; Kruse, L.; Müssig, J. Development of a DNA-analytical Method for the Identification of Animal Hair Fibers in Textiles. Text. Res. J. 2009, 79, 69-75. [CrossRef]

9. Tsai, S.Y.; Sennett, R.; Rezza, A.; Clavel, C.; Grisanti, L.; Zemla, R.; Najam, S.; Rendl, M. Wnt/ $\beta$-catenin signaling in dermal condensates is required for hair follicle formation. Dev. Biol. 2014, 385, 179-188. [CrossRef]

10. Enshell-Seijffers, D.; Lindon, C.; Kashiwagi, M.; Morgan, B.A. $\beta$-catenin activity in the dermal papilla regulates morphogenesis and regeneration of hair. Dev. Cell 2010, 18, 633-642. [CrossRef]

11. Veltri, A.; Lang, C.; Lien, W.H. Concise Review: Wnt Signaling Pathways in Skin Development and Epidermal Stem Cells. Stem Cells 2018, 36, 22-35. [CrossRef] [PubMed]

12. Yuhki, M.; Yamada, M.; Kawano, M.; Iwasato, T.; Itohara, S.; Yoshida, H.; Ogawa, M.; Mishina, Y. BMPR1A signaling is necessary for hair follicle cycling and hair shaft differentiation in mice. Development 2004, 131, 1825-1833. [CrossRef] [PubMed]

13. Kulessa, H.; Turk, G.; Hogan, B.L.M. Inhibition of Bmp signaling affects growth and differentiation in the anagen hair follicle. EMBO J. 2000, 19, 6664-6674. [CrossRef] [PubMed]

14. Woo, W.M.; Zhen, H.H.; Oro, A.E. Shh maintains dermal papilla identity and hair morphogenesis via a Noggin-Shh regulatory loop. Genes Dev. 2012, 26, 1235-1246. [CrossRef]

15. Zak, M.; Klis, S.F.; Grolman, W. The Wnt and Notch signalling pathways in the developing cochlea: Formation of hair cells and induction of regenerative potential. International journal of developmental neuroscience. Off. J. Int. Soc. Dev. Neurosci. 2015, 47, 247-258. [CrossRef]

16. Rosenquist, T.A.; Martin, G.R. Fibroblast growth factor signalling in the hair growth cycle: Expression of the fibroblast growth factor receptor and ligand genes in the murine hair follicle. Developmental dynamics. Off. Publ. Am. Assoc. Anat. 1996, 205, 379-386. [CrossRef]

17. Choi, Y.M.; Choi, S.Y.; Kim, H.; Kim, J.; Ki, M.S.; An, I.-S.; Jung, J. TGF $\beta$ family mimetic peptide promotes proliferation of human hair follicle dermal papilla cells and hair growth in C57BL/6 mice. Biomed. Dermatol. 2018, 2, 23. [CrossRef]

18. Yang, F.; Liu, Z.; Zhao, M.; Mu, Q.; Che, T.; Xie, Y.; Ma, L.; Mi, L.; Li, J.; Zhao, Y. Skin transcriptome reveals the periodic changes in genes underlying cashmere (ground hair) follicle transition in cashmere goats. BMC Genom. 2020, 21, 392. [CrossRef]

19. Zhao, W.; Langfelder, P.; Fuller, T.; Dong, J.; Li, A.; Hovarth, S. Weighted gene coexpression network analysis: State of the art. J. Biopharm. Stat. 2010, 20, 281-300. [CrossRef]

20. Zhang, B.; Horvath, S. A General Framework for Weighted Gene Co-Expression Network Analysis. Stat. Appl. Genet. Mol. Biol. 2005, 4, 1-45. [CrossRef]

21. Langfelder, P.; Horvath, S. WGCNA: An R package for weighted correlation network analysis. BMC Bioinform. 2008,9 , 559. [CrossRef]

22. Eidsaa, M.; Stubbs, L.; Almaas, E. Comparative analysis of weighted gene co-expression networks in human and mouse. PLoS ONE 2017, 12, e0187611. [CrossRef]

23. van Dam, S.; Vosa, U.; van der Graaf, A.; Franke, L.; de Magalhaes, J.P. Gene co-expression analysis for functional classification and gene-disease predictions. Brief. Bioinform. 2018, 19, 575-592. [CrossRef]

24. Kogelman, L.J.A.; Byrne, K.; Vuocolo, T.; Watson-Haigh, N.S.; Kadarmideen, H.N.; Kijas, J.W.; Oddy, H.V.; Gardner, G.E.; Gondro, C.; Tellam, R.L. Genetic architecture of gene expression in ovine skeletal muscle. BMC Genom. 2011, 12, 607. [CrossRef]

25. McDowall, M.L.; Watson-Haigh, N.S.; Edwards, N.M.; Kadarmideen, H.N.; Nattrass, G.S.; McGrice, H.A.; Hynd, P.I. Transient treatment of pregnant Merino ewes with modulators of cortisol biosynthesis coinciding with primary wool follicle initiation alters lifetime wool growth. Anim. Prod. Sci. 2013, 53, 1101. [CrossRef] 
26. Alexandre, P.A.; Gomes, R.C.; Santana, M.H.; Silva, S.L.; Leme, P.R.; Mudadu, M.A.; Regitano, L.C.; Meirelles, F.V.; Ferraz, J.B.; Fukumasu, H. Bovine NR1I3 gene polymorphisms and its association with feed efficiency traits in Nellore cattle. Meta Gene 2014, 2, 206-217. [CrossRef]

27. Ponsuksili, S.; Siengdee, P.; Du, Y.; Trakooljul, N.; Murani, E.; Schwerin, M.; Wimmers, K. Identification of common regulators of genes in co-expression networks affecting muscle and meat properties. PLoS ONE 2015, 10, e0123678. [CrossRef]

28. Miao, L.; Yin, R.X.; Pan, S.L.; Yang, S.; Yang, D.Z.; Lin, W.X. Weighted Gene Co-Expression Network Analysis Identifies Specific Modules and Hub Genes Related to Hyperlipidemia. Cellular physiology and biochemistry. Int. J. Exp. Cell. Physiol. Biochem. Pharmacol. 2018, 48, 1151-1163. [CrossRef]

29. Leinonen, R.; Sugawara, H.; Shumway, M.; International Nucleotide Sequence Database Collaboration. The sequence read archive. Nucleic Acids Res. 2011, 39, 19-21. [CrossRef]

30. Bolger, A.M.; Lohse, M.; Usadel, B. Trimmomatic: A flexible trimmer for Illumina sequence data. Bioinformatics 2014, 30, 2114-2120. [CrossRef] [PubMed]

31. Pertea, M.; Kim, D.; Pertea, G.M.; Leek, J.T.; Salzberg, S.L. Transcript-level expression analysis of RNA-seq experiments with HISAT, StringTie and Ballgown. Nat. Protoc. 2016, 11, 1650-1667. [CrossRef] [PubMed]

32. Kim, D.; Langmead, B.; Salzberg, S.L. HISAT: A fast spliced aligner with low memory requirements. Nat. Methods 2015, 12, 357-360. [CrossRef]

33. Liao, Y.; Smyth, G.K.; Shi, W. featureCounts: An efficient general purpose program for assigning sequence reads to genomic features. Bioinformatics 2014, 30, 923-930. [CrossRef]

34. Pertea, M.; Pertea, G.M.; Antonescu, C.M.; Chang, T.C.; Mendell, J.T.; Salzberg, S.L. StringTie enables improved reconstruction of a transcriptome from RNA-seq reads. Nat. Biotechnol. 2015, 33, 290-295. [CrossRef] [PubMed]

35. Langfelder, P.; Zhang, B.; Horvath, S. Defining clusters from a hierarchical cluster tree: The Dynamic Tree Cut package for R. Bioinformatics 2008, 24, 719-720. [CrossRef]

36. Chen, S.; Yang, D.; Lei, C.; Li, Y.; Sun, X.; Chen, M.; Wu, X.; Zheng, Y. Identification of crucial genes in abdominal aortic aneurysm by WGCNA. PeerJ 2019, 7, e7873. [CrossRef]

37. Guo, D.; Wang, H.; Sun, L.; Liu, S.; Du, S.; Qiao, W.; Wang, W.; Hou, G.; Zhang, K.; Li, C.; et al. Identification of key gene modules and hub genes of human mantle cell lymphoma by coexpression network analysis. PeerJ 2020, 8, e8843. [CrossRef]

38. Di, Y.; Chen, D.; Yu, W.; Yan, L. Bladder cancer stage-associated hub genes revealed by WGCNA co-expression network analysis. Hereditas 2019, 156, 7. [CrossRef]

39. Fuller, T.F.; Ghazalpour, A.; Aten, J.E.; Drake, T.A.; Lusis, A.J.; Horvath, S. Weighted gene coexpression network analysis strategies applied to mouse weight. Mammalian genome. Off. J. Int. Mamm. Genome Soc. 2007, 18, 463-472. [CrossRef]

40. Giulietti, M.; Occhipinti, G.; Principato, G.; Piva, F. Weighted gene co-expression network analysis reveals key genes involved in pancreatic ductal adenocarcinoma development. Cell. Oncol. 2016, 39, 379-388. [CrossRef]

41. Zhang, Q.; Ma, C.; Gearing, M.; Wang, P.G.; Chin, L.S.; Li, L. Integrated proteomics and network analysis identifies protein hubs and network alterations in Alzheimer's disease. Acta Neuropathol. Commun. 2018, 6, 19. [CrossRef] [PubMed]

42. Raudvere, U.; Kolberg, L.; Kuzmin, I.; Arak, T.; Adler, P.; Peterson, H.; Vilo, J. g:Profiler: A web server for functional enrichment analysis and conversions of gene lists (2019 update). Nucleic Acids Res. 2019, 47, 191-198. [CrossRef] [PubMed]

43. Dai, D.; Shi, R.; Han, S.; Jin, H.; Wang, X. Weighted gene coexpression network analysis identifies hub genes related to KRAS mutant lung adenocarcinoma. Medicine 2020, 99, e21478. [CrossRef] [PubMed]

44. Chin, C.H.; Chen, S.H.; Wu, H.H.; Ho, C.W.; Ko, M.T.; Lin, C.Y. cytoHubba: Identifying hub objects and sub-networks from complex interactome. BMC Syst. Biol. 2014, 8, S11. [CrossRef]

45. Shannon, P.; Markiel, A.; Ozier, O.; Baliga, N.S.; Wang, J.T.; Ramage, D.; Amin, N.; Schwikowski, B.; Ideker, T. Cytoscape: A software environment for integrated models of biomolecular interaction networks. Genome Res. 2003, 13, 2498-2504. [CrossRef]

46. Li, C.Y.; Cai, J.H.; Tsai, J.J.P.; Wang, C.C.N. Identification of Hub Genes Associated with Development of Head and Neck Squamous Cell Carcinoma by Integrated Bioinformatics Analysis. Front. Oncol. 2020, 10, 681. [CrossRef]

47. Yang, H.; Wang, Y.; Zhang, Z.; Li, H. Identification of KIF18B as a Hub Candidate Gene in the Metastasis of Clear Cell Renal Cell Carcinoma by Weighted Gene Co-expression Network Analysis. Front. Genet. 2020, 11, 905. [CrossRef]

48. Li, Z.; Chyr, J.; Jia, Z.; Wang, L.; Hu, X.; Wu, X.; Song, C. Identification of Hub Genes Associated with Hypertension and Their Interaction with miRNA Based on Weighted Gene Coexpression Network Analysis (WGCNA) Analysis. Med. Sci. Monit. Int. Med. J. Exp. Clin. Res. 2020, 26, e923514.

49. Niemira, M.; Collin, F.; Szalkowska, A.; Bielska, A.; Chwialkowska, K.; Reszec, J.; Niklinski, J.; Kwasniewski, M.; Kretowski, A. Molecular Signature of Subtypes of Non-Small-Cell Lung Cancer by Large-Scale Transcriptional Profiling: Identification of Key Modules and Genes by Weighted Gene Co-Expression Network Analysis (WGCNA). Cancers 2019, 12, 37. [CrossRef]

50. Robinson, M.D.; McCarthy, D.J.; Smyth, G.K. edgeR: A Bioconductor package for differential expression analysis of digital gene expression data. Bioinformatics 2010, 26, 139-140. [CrossRef]

51. Bastian, M.; Heymann, S.; Jacomy, M. Gephi: An Open Source Software for Exploring and Manipulating Networks. In Proceedings of the International AAAI Conference on Web and Social Media 2009, San Jose, CA, USA, 17-20 May 2009.

52. Jacomy, M.; Venturini, T.; Heymann, S.; Bastian, M. ForceAtlas2, a continuous graph layout algorithm for handy network visualization designed for the Gephi software. PLoS ONE 2014, 9, e98679. [CrossRef] [PubMed] 
53. Care, M.A.; Stephenson, S.J.; Barnes, N.A.; Fan, I.; Zougman, A.; El-Sherbiny, Y.M.; Vital, E.M.; Westhead, D.R.; Tooze, R.M.; Doody, G.M. Network Analysis Identifies Proinflammatory Plasma Cell Polarization for Secretion of ISG15 in Human Autoimmunity. J. Immunol. 2016, 197, 1447-1459. [CrossRef] [PubMed]

54. Carvalho, D.S.; Schnable, J.C.; Almeida, A.M.R. Integrating Phylogenetic and Network Approaches to Study Gene Family Evolution: The Case of the AGAMOUS Family of Floral Genes. Evol. Bioinform. Online 2018, 14. [CrossRef]

55. Di, J.; Xu, X.-M.; Ainiwaer, L.; Zhang, Y.-H.; Tian, K.-C.; Yu, L.-J.; Wu, W.-W.; Tulafu, H.; Fu, X.-F.; Yasen, M. Genome Array on Differentially Expressed Genes of Skin Tissue in Cashmere Goat at Early Anagen of Cashmere Growth Cycle Using DNA Microarray. J. Integr. Agric. 2014, 13, 2243-2252. [CrossRef]

56. Li, C.; Li, Y.; Zhou, G.; Gao, Y.; Ma, S.; Chen, Y.; Song, J.; Wang, X. Whole-genome bisulfite sequencing of goat skins identifies signatures associated with hair cycling. BMC Genom. 2018, 19, 638. [CrossRef]

57. Ge, W.; Tan, S.J.; Wang, S.H.; Li, L.; Sun, X.F.; Shen, W.; Wang, X. Single-cell Transcriptome Profiling reveals Dermal and Epithelial cell fate decisions during Embryonic Hair Follicle Development. Theranostics 2020, 10, 7581-7598. [CrossRef]

58. Messenger, A.G.; Elliott, K.; Temple, A.; Randall, V.A. Expression of basement membrane proteins and interstitial collagens in dermal papillae of human hair follicles. J. Investig. Dermatol. 1991, 96, 93-97. [CrossRef]

59. Oliver, R.F. The induction of hair follicle formation in the adult hooded rat by vibrissa dermal papillae. J. Embryol. Exp. Morphol. 1970, 23, 219-236.

60. Taylor, M.; Ashcroft, A.T.; Westgate, G.E.; Gibson, W.T.; Messenger, A.G. Glycosaminoglycan synthesis by cultured human hair follicle dermal papilla cells: Comparison with non-follicular dermal fibroblasts. Br. J. Dermatol. 1992, 126, 479-484. [CrossRef]

61. Young, R.D. Morphological and ultrastructural aspects of the dermal papilla during the growth cycle of the vibrissal follicle in the rat. J. Anat. 1980, 131, 355-365.

62. Chen, Y.; Huang, J.; Chen, R.; Yang, L.; Wang, J.; Liu, B.; Du, L.; Yi, Y.; Jia, J.; Xu, Y.; et al. Sustained release of dermal papilla-derived extracellular vesicles from injectable microgel promotes hair growth. Theranostics 2020, 10, 1454-1478. [CrossRef]

63. Young, T.H.; Tu, H.R.; Chan, C.C.; Huang, Y.C.; Yen, M.H.; Cheng, N.C.; Chiu, H.C.; Lin, S.J. The enhancement of dermal papilla cell aggregation by extracellular matrix proteins through effects on cell-substratum adhesivity and cell motility. Biomaterials 2009, 30, 5031-5040. [CrossRef] [PubMed]

64. Kuo, J.C. Focal adhesions function as a mechanosensor. Prog. Mol. Biol. Transl. Sci. 2014, 126, 55-73. [PubMed]

65. Yoon, S.Y.; Dieterich, L.C.; Tacconi, C.; Sesartic, M.; He, Y.; Brunner, L.; Kwon, O.; Detmar, M. An important role of podoplanin in hair follicle growth. PLoS ONE 2019, 14, e0219938. [CrossRef]

66. Chen, Y.; Fan, Z.; Wang, X.; Mo, M.; Zeng, S.B.; Xu, R.H.; Wang, X.; Wu, Y. PI3K/Akt signaling pathway is essential for de novo hair follicle regeneration. Stem Cell Res. Ther. 2020, 11, 144. [CrossRef]

67. Choudhary, V.; Olala, L.O.; Kagha, K.; Pan, Z.Q.; Chen, X.; Yang, R.; Cline, A.; Helwa, I.; Marshall, L.; Kaddour-Djebbar, I.; et al. Regulation of the Glycerol Transporter, Aquaporin-3, by Histone Deacetylase-3 and p53 in Keratinocytes. J. Investig. Dermatol. 2017, 137, 1935-1944. [CrossRef]

68. Hara-Chikuma, M.; Verkman, A.S. Roles of aquaporin-3 in the epidermis. J. Investig. Dermatol. 2008, 128, 2145-2151. [CrossRef]

69. Qin, H.; Zheng, X.; Zhong, X.; Shetty, A.K.; Elias, P.M.; Bollag, W.B. Aquaporin-3 in keratinocytes and skin: Its role and interaction with phospholipase D2. Arch. Biochem. Biophys. 2011, 508, 138-143. [CrossRef]

70. Nakahigashi, K.; Kabashima, K.; Ikoma, A.; Verkman, A.S.; Miyachi, Y.; Hara-Chikuma, M. Upregulation of aquaporin-3 is involved in keratinocyte proliferation and epidermal hyperplasia. J. Investig. Dermatol. 2011, 131, 865-873. [CrossRef]

71. Bollag, W.B.; Xie, D.; Zheng, X.; Zhong, X. A potential role for the phospholipase D2-aquaporin-3 signaling module in early keratinocyte differentiation: Production of a phosphatidylglycerol signaling lipid. J. Investig. Dermatol. 2007, 127, $2823-2831$. [CrossRef]

72. Qin, H.; Bollag, W.B. The caveolin-1 scaffolding domain peptide decreases phosphatidylglycerol levels and inhibits calciuminduced differentiation in mouse keratinocytes. PLoS ONE 2013, 8, e80946. [CrossRef] [PubMed]

73. Wu, J.; Li, Y.; Gong, H.; Wu, D.; Li, C.; Liu, B. Circannual Rhythm in the Skin Gene Expression of Cashmere Goat. bioRxiv 2020, 23-44. [CrossRef]

74. Rogers, M.A.; Langbein, L.; Winter, H.; Ehmann, C.; Praetzel, S.; Schweizer, J. Characterization of a first domain of human high glycine-tyrosine and high sulfur keratin-associated protein (KAP) genes on chromosome 21q22.1. J. Biol. Chem. 2002, 277, 48993-49002. [CrossRef] [PubMed]

75. Zhao, Z.; Liu, G.; Li, X.; Huang, J.; Xiao, Y.; Du, X.; Yu, M. Characterization of the Promoter Regions of Two Sheep KeratinAssociated Protein Genes for Hair Cortex-Specific Expression. PLoS ONE 2016, 11, e0153936. [CrossRef]

76. Andrews, M.; Visser, C.; van Marle-Köster, E. Identification of novel variants for KAP 1.1, KAP 8.1 and KAP 13.3 in South African goats. Small Rumin. Res. 2017, 149, 176-180. [CrossRef]

77. Pruett, N.D.; Tkatchenko, T.V.; Jave-Suarez, L.; Jacobs, D.F.; Potter, C.S.; Tkatchenko, A.V.; Schweizer, J.; Awgulewitsch, A. Krtap16, characterization of a new hair keratin-associated protein (KAP) gene complex on mouse chromosome 16 and evidence for regulation by Hoxc13. J. Biol. Chem. 2004, 279, 51524-51533. [CrossRef]

78. Liang, S.; Bao, Z.; Zhao, B.; Zhou, T.; Li, J.; Liu, M.; Hu, S.; Yang, N.; Chen, Y.; Wu, X. Characterization and functional analysis of Krtap11-1 during hair follicle development in Angora rabbits (Oryctolagus cuniculus). Genes Genom. 2020, 42, 1281-1290. [CrossRef] 
79. Zhou, G.; Kang, D.; Ma, S.; Wang, X.; Gao, Y.; Yang, Y.; Wang, X.; Chen, Y. Integrative analysis reveals ncRNA-mediated molecular regulatory network driving secondary hair follicle regression in cashmere goats. BMC Genom. 2018, 19, 222. [CrossRef]

80. Geyfman, M.; Plikus, M.V.; Treffeisen, E.; Andersen, B.; Paus, R. Resting no more: Re-defining telogen, the maintenance stage of the hair growth cycle. Biol. Rev. Camb. Philos. Soc. 2015, 90, 1179-1196. [CrossRef]

81. Plikus, M.V.; Baker, R.E.; Chen, C.C.; Fare, C.; de la Cruz, D.; Andl, T.; Maini, P.K.; Millar, S.E.; Widelitz, R.; Chuong, C.M. Self-organizing and stochastic behaviors during the regeneration of hair stem cells. Science 2011, 332, 586-589. [CrossRef]

82. Eckhardt, M.; Yaghootfam, A.; Fewou, S.N.; Zöller, I.; Gieselmann, V. A mammalian fatty acid hydroxylase responsible for the formation of $\alpha$-hydroxylated galactosylceramide in myelin. Biochem. J. 2005, 388, 245-254. [CrossRef] [PubMed]

83. Maier, H.; Meixner, M.; Hartmann, D.; Sandhoff, R.; Wang-Eckhardt, L.; Zoller, I.; Gieselmann, V.; Eckhardt, M. Normal fur development and sebum production depends on fatty acid 2-hydroxylase expression in sebaceous glands. J. Biol. Chem. 2011, 286, 25922-25934. [CrossRef] [PubMed]

84. Madison, K.C. Barrier Function of the Skin: "La Raison d'Être" of the Epidermis. J. Investig. Dermatol. 2003, 121, $231-241$. [CrossRef] [PubMed]

85. Potter, K.A.; Kern, M.J.; Fullbright, G.; Bielawski, J.; Scherer, S.S.; Yum, S.W.; Li, J.J.; Cheng, H.; Han, X.; Venkata, J.K.; et al. Central nervous system dysfunction in a mouse model of FA2H deficiency. Glia 2011, 59, 1009-1021. [CrossRef] [PubMed]

86. Chuong, C.M.; Nickoloff, B.J.; Elias, P.M.; Goldsmith, L.A.; Macher, E.; Maderson, P.A.; Sundberg, J.P.; Tagami, H.; Plonka, P.M.; Thestrup-Pederson, K.; et al. What is the 'true' function of skin? Exp. Dermatol. 2002, 11, 159-187.

87. Armstrong, L.; Tilgner, K.; Saretzki, G.; Atkinson, S.P.; Stojkovic, M.; Moreno, R.; Przyborski, S.; Lako, M. Human induced pluripotent stem cell lines show stress defense mechanisms and mitochondrial regulation similar to those of human embryonic stem cells. Stem Cells 2010, 28, 661-673. [CrossRef] [PubMed]

88. Hamanaka, R.B.; Chandel, N.S. Mitochondrial metabolism as a regulator of keratinocyte differentiation. Cell. Logist. 2013, 3, e25456. [CrossRef]

89. Singh, B.; Schoeb, T.R.; Bajpai, P.; Slominski, A.; Singh, K.K. Reversing wrinkled skin and hair loss in mice by restoring mitochondrial function. Cell Death Dis. 2018, 9, 735. [CrossRef]

90. Bodemer, C.; Rotig, A.; Rustin, P.; Cormier, V.; Niaudet, P.; Saudubray, J.M.; Rabier, D.; Munnich, A.; de Prost, Y. Hair and skin disorders as signs of mitochondrial disease. Pediatrics 1999, 103, 428-433. [CrossRef] 